\title{
The Expression of R-gene Resistance to Phytophthora infestans in Tissue Cultures of Solanum tuberosum
}

\author{
By D. S. INGRAM* \\ Department of Botany, The University of Hull \\ (Accepted for publication I8 April 1967)
}

SUMMAR Y

The expression of R-gene resistance in tissue cultures of Solanum species was investigated. Tissue aggregates ( $4 \mathrm{~mm}$. diam.) of Solanum tuberosum var. Majestic (rr) and Orion (R 1 ) and other R-gene Solanum lines behaved in a similar way to the intact plants from which they were derived, in response to Phytophthora infestans race 4. Tissue aggregates of $S$. tuberosum var. Orion supported good growth of $P$. infestans race 1 , to which the intact Orion plant is susceptible, but did not support more than rudimentary growth of race 4, to which the intact Orion plant is resistant. Sectioning revealed that $P$. infestans race 4 made general growth in Majestic tissues, but was almost totally excluded from Orion tissues. A slide technique showed that Orion tissue suspensions, unlike those of Majestic, inhibited the growth of $P$. infestans race 4 germ tubes. This led to a demonstration that toxicity to $P$. infestans zoospores was developed in Orion but not in Majestic tissue cultures in response to infection with $P$. infestans race 4 . It was concluded that $\mathbf{R}$-genes may be expressed in tissue culture, that the failure of the Orion tissue to support growth of $P$. infestans may be due to expression of the R I gene, and that this may operate through the development of post infectional toxicity.

\section{INTRODUCTION}

Hypersensitive or R-gene resistance in Solanum species leads, after initial penetration of a small group of cells, to the rapid exclusion of incompatible races of Phytophthora infestans (Ferris, 1955; Müller 1950). This is the case with $S$. tuberosum var. Orion, where $P$. infestans race 4 is unable to make any growth on either leaves or tubers as a result of the function of the R I gene (Lapwood \& McKee, I96I). In contrast, race 4 makes general and unrestricted growth in the susceptible $S$. tuberosum var. Majestic plant. Müller \& Börger (I940) postulated that in the potato, hypersensitive resistance was due to a rapid development of antibiotics in the tissues in response to infection. The substances responsible were termed 'phytoalexins', and the phytoalexin concept has since been developed further for $S$. tuberosum and for other plant/fungus combinations (Cruickshank, 1963). Ingram \& Robertson (1965) showed that tissue cultures of $S$. tuberosum var. Majestic supported good growth of $P$. infestans race 4 , whereas var. Orion tissues supported only rudimentary growth of this fungus. The situation corresponded exactly with observations made with intact plants, and it was suggested that the failure of the Orion tissues to support fungal growth was due to the expression of the R I gene in tissue culture. The expression of R-genes in tissue

\footnotetext{
* Present address: Department of Botany, University of Glasgow.
} 
cultures of Solanum species, and in particular in tissue cultures of $S$. tuberosum var. Orion, has now been further investigated.

\section{METHODS}

Organisms. Phytophthora infestans race I was isolated from a leaf of Solanum tuberosum var. Orion, and race 4 from a leaf of var. Duke of York during July 1964. Race I was found to be pathogenic to leaflets and to half tubers of both $S$. tuberosum var. Majestic and var. Orion, while race 4 was pathogenic only to Majestic, and nonpathogenic to Orion. These and other pathogenicity tests were made by inoculating leaflets and half tubers contained in humidity chambers with $\mathrm{I} \times \mathrm{IO}^{3}$ sporangia suspended in $0.01 \mathrm{ml}$. of distilled water.

Tubers of Solanum tuberosum var. Majestic (rr) and var. Orion (R I) were maintained as tissue cultures. For specific experiments tissue cultures were initiated from stems and tubers of $S$. tuberosum var. Ulster Torch (R $\mathrm{I})$, tubers of var. Pentland Beauty (R 3 ) and stems of Solanum demissum (R4) and Solanum stoloniferum (R 2). Normal (i.e. not cultured) material was obtained from field-grown plants in the case of the $S$. tuberosum varieties and from pot-grown plants in the case of $S$. demissum and S. stoloniferum.

Media used for the establishment and maintenance of tissue cultures, and for the maintenance of Phytophthora infestans stock cultures, were as described by Ingram \& Robertson (1965). The tissue culture medium, either in liquid form or solidified with $\mathrm{I} \%(\mathrm{w} / \mathrm{v})$ Davis agar, was used in all experiments. This medium did not support colonial growth of $P$. infestans from spores.

Establishment and maintenance of tissue cultures. Solanum tuberosum tuber callus cultures were established according to the procedure of Ingram \& Robertson (1965). This procedure was modified slightly for the initiation of stem-tissue cultures as follows: $3 \mathrm{~cm}$. internode segments from mature plants were surface sterilized in $95 \%(\mathrm{v} / \mathrm{v})$ ethanol in water for I min., then in a saturated calcium hypochlorite solution for $7 \mathrm{~min}$., and washed several times in glass-distilled water. A $\mathrm{I} \mathrm{cm}$. length of tissue was then cut from the centre of each segment and placed on $15 \mathrm{ml}$. of solidified medium contained in a 6 in. $\times I$ in. Pyrex glass culture tube, and incubated at $25^{\circ}$. Callus growth from the cut ends of the inocula was normally visible after $\mathrm{I}-4$ weeks, and after 6-8 weeks it was removed from the original explant and transferred to fresh medium. For a supply of experimental material calluses were transferred to shake culture where the growing tissue mass broke up to give suspensions of single cells and tissue aggregates of up to $5.0 \mathrm{~mm}$. diameter (Ingram \& Robertson, 1965).

Preparation of spore suspensions. Seven-day-old bean-medium slopes of Phytophthora infestans grown at $22^{\circ}$ were used as source of spores. Sporangial suspensions were prepared by washing 7 -day cultures with $10 \mathrm{ml}$. liquid tissue culture medium. In this medium the sporangia germinated directly and did not produce zoospores. When zoospores were required, 7-day $22^{\circ}$ cultures were left overnight at $10^{\circ}$, after which sporangia were removed in $10 \mathrm{ml}$. sterile distilled water and the suspension incubated at $10^{\circ}$ for $2 \mathrm{hr}$. Zoospores were produced when the suspensions were brought to room temperature, and could be pipetted from the top of the liquid, empty and ungerminated sporangia having settled out.

Inoculation of tissue aggregates. Small aggregates of tissue, about $4.0 \mathrm{~mm}$. in diam., 
were removed from liquid culture with a wire loop and placed on the surface of the solidified tissue culture medium in Petri plates. Sporangia of $P$. infestans, $1 \times 10^{3}$ suspended in $0.02 \mathrm{ml}$. liquid medium, were applied to the tissues with a sterile pipette. Incubation was at $22^{\circ}$. Wherever possible all treatments in an experiment were placed in the same Petri plate and replicated at least Io times. In this way environmental variation between treatments was virtually eliminated.

Histological investigations. Tissue aggregates ( $4 \mathrm{~mm}$. diam.) were transferred from liquid culture to agar plates and each aggregate inoculated with $\mathrm{I} \times 10^{3}$ sporangia of Phytophthora infestans race 4. After incubation for 7 days at $22^{\circ}$ the infected tissues were removed from the agar, fixed in formalin + acetic acid + ethanol, dehydrated by the tert.-butanol procedure and embedded in paraffin wax (Johansen, 1940). Sections ( $8 \mu$ thick) were cut and after being mounted were stained, either with $0.01 \%$ cotton blue in lactophenol and mounted in lactophenol, or with Delafield's haematoxylin (Gray, 1954) and mounted in Canada balsam. Attempts to stain the material with carbol thionin blue (Stoughton, 1930) produced indifferent results.

Slide germination experiments. These experiments were done under completely sterile conditions at $22^{\circ}$. Thoroughly clean $3.0 \mathrm{in} . \times \mathrm{I} \cdot 0$ in. glass microscope slides were supported on glass rods over a thin film of distilled water in Petri dishes. The slides were inoculated near the centre with $0.1 \mathrm{ml}$. of a cell suspension and with $0.05 \mathrm{ml}$. distilled water containing $\mathrm{I} \times 10^{4}$ Phytophthora zoospores. The film of distilled water maintained a high humidity in the Petri dishes, so that there was little evaporation from the drops of liquid on the slides, even after 7 days. Sample slides were examined microscopically as required, and after examination were usually discarded because of the loss of sterility. It was found that a small drop of cotton blue in lactophenol often facilitated microscopic examination, and when germ tubes were to be measured a drop of this stain was added at the same time to all slides to be examined, to halt growth of the fungus.

Tissue cultures used in these experiments were from tubers of Solanum tuberosum var. Majestic and var. Orion. Cultures were grown from $5.0 \mathrm{ml}$. tissue suspension inoculum in $20 \mathrm{ml}$. liquid medium contained in $100 \mathrm{ml}$. Erlenmeyer flasks. The cultures were incubated on the shaker for 8 weeks, and $10 \mathrm{ml}$. fresh medium was added after 4 weeks of growth. Dense cultures consisting predominantly of single cells or small groups of cells (up to 20) were selected for use, and a small quantity of the cell suspension removed with a sterile Pasteur pipette. A single drop of cell suspension delivered from such a pipette normally had a volume of about $0.05 \mathrm{ml}$. In individual experiments cells for all replicates and treatments of a tissue variety were taken from the same culture.

Tissue culture filtrate experiments. Erlenmeyer flasks ( $100 \mathrm{ml}$.) each containing $25 \mathrm{ml}$. of a dense 8-week Solanum tuberosum tissue suspension were used. Each flask was inoculated with $2 \times 10^{5}$ sporangia of Phytophthora infestans and incubated on a shaker at $22^{\circ}$. About $0.5 \mathrm{ml}$. liquid ('filtrate') was removed from each flask just before inoculation and at 24, 48, 72, 96 and $168 \mathrm{hr}$ after inoculation. This liquid was assayed against Phytophthora infestans zoospores on glass slides. Each slide was inoculated with $0 . \mathrm{I} \mathrm{ml}$. of the liquid and with $\mathrm{I} \times 10^{4}$ zoospores in $0.05 \mathrm{ml}$. distilled water, and incubated at $22^{\circ}$ for $4 \mathrm{hr}$. Percentage germination of zoospores was calculated from the total spore counts in three low power $(750 \mu$ diameter) microscope fields for each of two slides (about 100 spores/field) for each treatment. 


\section{RESULTS}

Growth of Phytophthora infestans race 4 on Solanum tissue aggregates of various $R$-genotypes

The growth of Phytophthora infestans race 4 from sporangia was tested on tissue aggregates derived from in vitro cultures of several R-gene Solanum lines. These lines were: Solanum tuberosum var. Majestic (rr, tuber), var. Orion (R I, tuber), var. Ulster Torch (R I, tuber and stem), var. Pentland Beauty (R 3, tuber), S. demissum (R 4, stem), $S$. stoloniferum (R 2 [McKee, 1962], stem). The results of the tests, together with the reaction to sporangial infection of leaflets and half tubers of the varieties concerned are given in Table I. Tissue cultures derived from resistant Solanum plants did not support growth of $P$. infestans race 4 , while tissue cultures derived from susceptible plants supported good growth of this fungus. (The R 2, R 3 and R 4 genes, unlike the $\mathrm{R}$ I gene, are only partially expressed in tubers [Lapwood \& McKee, 196I].)

Table I. The growth of Phytophthora infestans race 4 from sporangia on tissue cultures and on leaflets and half tubers of the Solanum lines from which the tissue cultures were derived

Reactions: $\mathbf{S}=$ susceptible reaction, profuse growth of the fungus; $\mathbf{R}=$ resistant reaction, little or no growth of the fungus; $\mathbf{H}=$ resistant reaction of leaflets, production of hypersensitive flecks; N.T. = not tested

\begin{tabular}{|c|c|c|c|c|c|}
\hline \multirow[b]{3}{*}{ Solanum variety } & \multirow[b]{3}{*}{ R-genotype } & \multicolumn{4}{|c|}{ Reaction to infection } \\
\hline & & \multicolumn{2}{|c|}{ Tissue cultures } & \multicolumn{2}{|c|}{ Plant parts } \\
\hline & & Tuber & Stem & Half tubers & Leaflets \\
\hline \multicolumn{6}{|l|}{ S. tuberosum } \\
\hline var. Majestic & $\mathrm{rr}$ & $\mathbf{S}$ & N.T. & $\mathbf{S}$ & $\mathbf{S}$ \\
\hline var. Orion & $\mathbf{R}_{\text {I }}$ & $\mathbf{R}$ & N.T. & $\mathbf{R}$ & $\tilde{H}$ \\
\hline var. Ulster Torch & $\mathbf{R}_{\text {I }}$ & $\mathbf{R}$ & $\mathbf{R}$ & $\mathbf{R}$ & $\mathrm{H}$ \\
\hline var. Pentland Beauty & $\mathbf{R}_{3}$ & $\mathbf{S}$ & N.T. & $\mathbf{S}$ & $\mathbf{H}$ \\
\hline S. demissum & $\mathbf{R}_{4}$ & N.T. & $\mathbf{S}$ & N.T. & $\mathbf{S}$ \\
\hline S. stoloniferum & $\mathrm{R}_{2}$ & N.T. & $\mathbf{R}$ & N.T. & $\mathbf{H}$ \\
\hline
\end{tabular}

The growth of Phythophthora infestans race I on tissue aggregates of Solanum tuberosum var. Orion

Solanum tuberosum var. Orion tissue aggregates inoculated with $\mathrm{I} \times \mathrm{IO}^{3}$ sporangia of Phytophthora infestans race I (to which the intact Orion plant is susceptible) were compared, on the same plate, with aggregates similarly inoculated with sporangia of race 4 . After incubation for 3 days considerable mycelial development had taken place on those tissue aggregates inoculated with sporangia of race $\mathrm{I}$, and at 7 days the colonies were between 1.5 and $2.5 \mathrm{~cm}$. diam. Only rudimentary mycelial growth took place on tissues inoculated with sporangia of race 4, even after ro days (Pl. I, fig. I). Both isolates were able to make good growth on similarly inoculated Majestic tissue aggregates.

Histology of tissue aggregates infected with Phytophthora infestans race 4

Serial sections of three Majestic and four Orion tissue aggregates were examined with the Delafield's haematoxylin stain 7 days after infection with sporangia of 
Phytophthora infestans race 4. Both types of tissue were found to consist basically of large thin-walled cells. These were roughly spherical in shape and 30-100 $\mu$ diameter. Within the matrix of large cells meristematic pockets up to $800 \mu$ diameter were occasionally noted. These consisted of a group of small cells, densely filled with cytoplasm, surrounded by a crushed zone, 4 or 5 cells thick. Tracheid-like, reticulately thickened cells were also observed; these were few in number, were not orientated, and usually occurred in groups of two or three. The bands of thickening did not stain red with phloroglucinol and hydrochloric acid, but gave a cellulose reaction with Schultze's solution ( $50 \mathrm{~g} . \mathrm{ZnCl}_{2}$ and $\mathrm{I} 6 \mathrm{~g}$. $\mathrm{KI}$ in $\mathrm{I} 7 \mathrm{ml}$. water + excess iodine). Starch was not a normal cell constituent in the tissue aggregates, but small grains between $7.5 \mu$ and $15.0 \mu$ diam. were often present in isolated groups of cells. Tissue aggregates generally had a number of deep, debris-filled fissures. The $P$. infestans exhibited quite different growth patterns in the tissue aggregates of the two varieties; each will be described separately.

In Solanum tuberosum var. Majestic. After incubation for 7 days the Phytophthora infestans had made good growth on these tissues, which had become soft and fragile. Within the tissues growth of the fungus was general and diffuse, with a loose unrestricted network of inter- and intracellular hyphae permeating the whole of the aggregate. In some instances the fungal hyphae proliferated within a single cell or small group of cells so that these became packed with mycelium. Two of the Majestic tissue aggregates examined had extensive areas of broken and separated cells, which appeared to have resulted from the direct activity of the $P$. infestans.

In Solanum tuberosum var. Orion. After 7 days the Phytophthora infestans made virtually no visible growth on the Orion aggregates, which remained quite firm. Sections showed that hyphae were almost totally absent from the tissues, though a few isolated cells near the surface of the aggregates had become infected and were packed with mycelium (Pl. I, fig. 2). No fungus was detected in cells adjacent to these or in cells away from the surface of the aggregates. Occasionally the $P$. infestans proliferated in debris-filled fissures, and the infection of tissues lining such structures was of a more general type, with inter- and intracellular hyphae extending to a depth of three or four cells. No tissue maceration was noted in any of the Orion material examined.

Two meristematic zones in one of the Orion tissue aggregates exhibited an unusual infection pattern. Both zones were exposed in part at the surface of the aggregate and, in contrast with surrounding tissues, were densely packed with Phytophthora infestans mycelium. Massive development of the fungus had taken place in the meristematic cells and in the surrounding zones of crushed cells. Similar meristematic pockets in Majestic tissue aggregates did not show this massive development of the fungus, but were diffusely infected in a similar way to the rest of the tissue aggregate in which they were situated.

Haustoria. The structure of the host/parasite interface was not clear in Delafield's haematoxylin preparations, but some detail of the region of contact between cells and individual hyphae was obtained when sections were stained with cotton blue and mounted in lactophenol. Preparations of tissue aggregate material were examined for haustoria by using this stain; no haustoria of the type described by Blackwell (1953) was detected. (Dr A. E. Godwin [personal communication] has seen similar haustoria.) However, small haustorium-like projections from hyphae were occasionally 
noted; these were $\mathrm{I} \cdot 5-2 \cdot 0 \mu$ long and penetrated cell walls. They lacked both the sheath and the basal constriction reported by other workers as being typical of Phytophthora infestans haustoria.

\section{Slide germination experiments}

In these experiments glass slides were simultaneously inoculated with a cell suspension of the resistant Solanum tuberosum var. Orion or the susceptible var. Majestic, and with zoospores of Phytophthora infestans race 4 .

Growth of zoospores germ tubes. The lengths of 25 separate germ tubes, in a sample slide from each treatment, where $\mathrm{I} \times 10^{4}$ zoospores had been incubated in the presence of $0.1 \mathrm{ml}$. cell suspension of Majestic or Orion, were measured after incubation for $24 \mathrm{hr}$ at $22^{\circ}$. There was significantly less growth of the germ tubes in the presence of Orion cells than in the presence of Majestic cells (Table 2). Substitution of $0.1 \mathrm{ml}$. of liquid medium in which no tissues had been grown, for the cell suspensions, resulted in a similar growth of germ tubes to that which had taken place in the presence of Majestic cells.

Table 2. Lengths of zoospore germ tubes for each treatment, where Phytophthora infestans race 4 zoospores were incubated for $24 \mathrm{hr}$ in the presence of cells of Solanum tuberosum var. Majestic and var. Orion and in unused liquid tissue culture medium

\begin{tabular}{|c|c|c|}
\hline & $\begin{array}{c}\text { Mean length of } \\
25 \text { germ tubes }(\mu)\end{array}$ & $\begin{array}{l}\mathrm{pH}^{*} \\
\text { value }\end{array}$ \\
\hline $\begin{array}{l}\text { Var. Majestic } \\
\text { Var. Orion } \\
\text { Liquid medium }\end{array}$ & 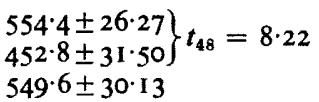 & $\begin{array}{l}5 \cdot 0 \\
4 \cdot 9 \\
5 \cdot 4\end{array}$ \\
\hline
\end{tabular}

* pH value of tissue cultures or uninoculated medium.

Penetration of cells. Cell slides of Majestic and Orion tissues were examined at 24, 48, 72 and $96 \mathrm{hr}$ after infection with Phytophthora infestans zoospores for penetration of cells by germ tubes. The number of penetrations was very low so that no reliable comparison could be made between the two varieties. However, the number of penetrated cells became greater with time, and certain clearly defined stages in cell penetration by germ tubes were noted.

At $24 \mathrm{hr}$ some of the germ tubes had become attached to cell walls by a small swelling resembling an appressorium, and could not be detached with the aid of a fine needle. From most of these appressoria an infection hypha with a constricted base had penetrated the cell wall (Fig. I A). At $48 \mathrm{hr}$ infection hyphae had usually branched within the infected cell, and in many cases had grown out through the wall at the other side (Fig. I B). The second point of wall penetration was also accompanied by an appressorium-like swelling at the point of contact between the hypha and the cell wall. At $96 \mathrm{hr}$ hyphae had usually made considerable growth within the infected cells (Fig. I C). All stages of penetration were represented in the $96 \mathrm{hr}$ slides.

\section{Germination of zoospores of Phytophthora infestans in tissue-culture filtrates}

Suspension cultures of Solanum tuberosum var. Majestic and var. Orion were infected with $2 \times 10^{5}$ sporangia of Phytophthora infestans race 4 and incubated on a shaker at $22^{\circ}$. Samples of the culture liquid (filtrate) were assayed against $P$. infestans race 4 zoospores on glass slides immediately before infection, and at 24, 48, 72, 96 and I $68 \mathrm{hr}$ after infection. 
Germination of zoospores in the Majestic filtrate was $100 \%$ at all times of testing. In Orion filtrate, germination of the zoospores was $100 \%$ immediately before infection and after $24 \mathrm{hr}$, but decreased to only $7 \%$ at $96 \mathrm{hr}$ and to $0.0 \%$ at $\mathrm{I} 68 \mathrm{hr}$ (Table 3; Fig. 2). At $48 \mathrm{hr}$ a few of the ungerminated zoospores burst. The proportion of burst zoospores became greater with time, and was $100 \%$ at $168 \mathrm{hr}$. Similar tests showed that the infected Orion culture liquid was equally toxic to zoospores of $P$. infestans race I (Table 4), but had no effect on the germination of spores of either Glomerella cingulata or Botrytis allii.
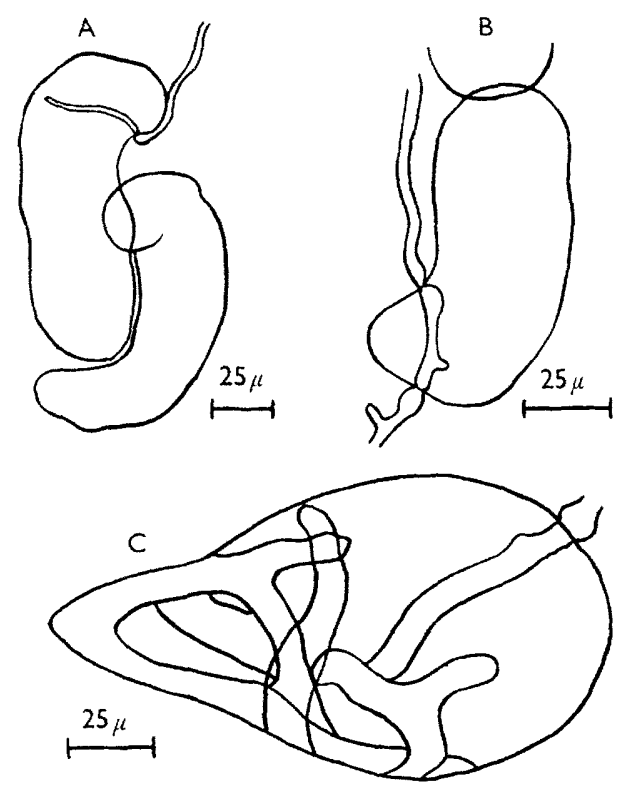

Fig. 1. Penetration of cells of Solanum tuberosum by germ tubes of Phytophthora infestans race $4 . \mathrm{A}, 24 \mathrm{hr} ; \mathrm{B}, 48 \mathrm{hr} ; \mathrm{C}, 96 \mathrm{hr}$.

Table 3. Germination of Phytophthora infestans race 4 zoospores in liquid taken from infected tissue cultures of Solanum tuberosum var. Majestic and var. Orion after various times

Liquid from
the variety
Var. Majestic

Var. Orion

Var. Majestic
Var. Orion

\begin{tabular}{rrrrrr}
\multicolumn{6}{c}{ Time (hr) } \\
\hline 0 & 24 & 48 & 72 & 96 & 168 \\
& & \multicolumn{1}{c}{ Germination (\%) } & & \\
\hline 100 & 100 & 100 & 100 & 100 & 100 \\
100 & 100 & 50 & 26 & 7 & 0
\end{tabular}

The toxicity of the $168 \mathrm{hr}$ culture liquid to $P$. infestans race 4 zoospores was modified by heat treatment: a sample which had been held at $100^{\circ}$ for I min. brought about no bursting of zoospores, while a sample which had been held at $100^{\circ}$ for $5 \mathrm{~min}$. allowed a small number of zoospores (less than $1 \%$ ) to germinate. 


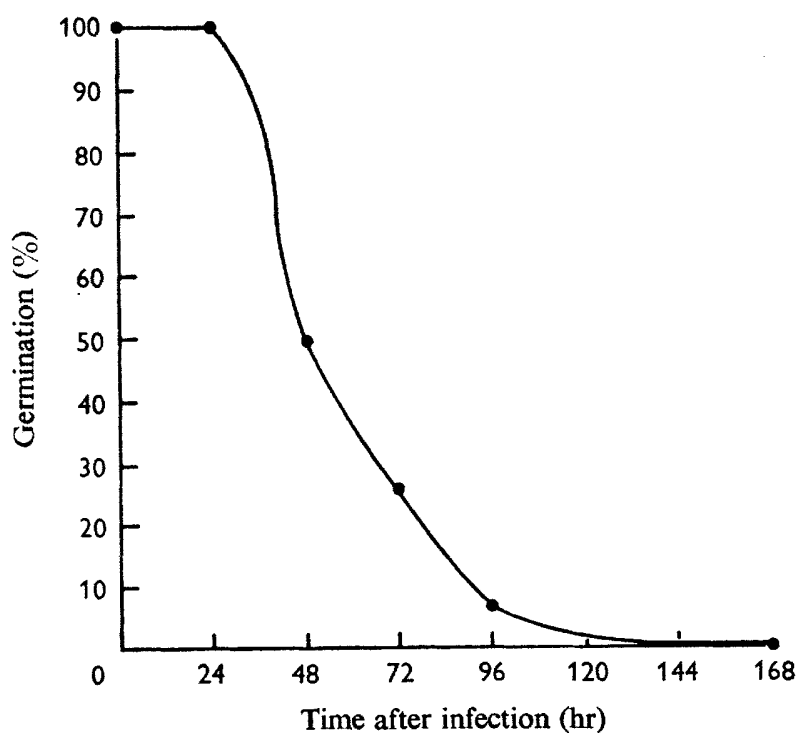

Fig. 2. Germination of Phytophthora infestans race 4 zoospores in liquid taken from an infected tissue culture of Solanum tuberosum var. Orion after various times.

Table 4. Germination of Phytophthora infestans race I zoospores in liquid taken from infected tissue cultures of Solanum tuberosum var. Majestic and var. Orion after various times Liquid from
the variety

Var. Majestic Var. Orion

\begin{tabular}{rrrrrr}
\hline 0 & 24 & 48 & 72 & 96 & 168 \\
& \multicolumn{6}{c}{ Germination (\%) } \\
100 & 100 & 100 & 100 & 100 & 100 \\
100 & 100 & 50 & 31 & 7 & 0
\end{tabular}

\section{DISCUSSION}

The suggestion that R-genes may be expressed in tissue culture (Ingram \& Robertson, 1965) is supported by the demonstration that Phytophthora infestans race 4 grew well on tissue culture aggregates derived from susceptible Solanum lines but made little growth on tissue cultures from resistant Solanum lines. Evidence for the R-gene nature of the Solanum tuberosum var. Orion tissue cultures is provided by the demonstration that tissue aggregates, which did not support growth of $P$. infestans race 4 , did support good growth of $P$. infestans race $\mathrm{I}$, an isolate which has been shown to be pathogenic to the intact Orion plant.

Sectioning revealed that Phytophthora infestans race 4 made unrestricted growth in the Solanum tuberosum var. Majestic tissue aggregates. This fungus was largely excluded from the $S$. tuberosum var. Orion aggregates, although a small number of cells were heavily infected. The infected cells situated near the surface of the tissue mass may previously have suffered damage, owing to their exposed position, or the $P$. infestans may have in some way overcome their resistance. Infection of cells lining 
fissures in the Orion aggregates might have resulted from the massive build up of fungal inoculum in the debris which invariably filled such structures.

The proliferation of Phytophthora infestans in meristematic pockets in Orion tissue aggregates is difficult to comprehend, unless it be assumed that young and actively dividing cells were less resistant than those which had reached maturity. Ingram (I966) showed the formation by some Orion tissue cultures of sectors which were only partially resistant to $P$. infestans race 4 . It is possible that those meristematic pockets in which the $P$. infestans proliferated may have been centres of initiation of such sectors.

The mechanism whereby Orion tissue aggregates were able to exclude Phytophthora infestans race 4 , and cell suspensions to inhibit the growth of germ tubes, is suggested by the results of the tissue culture filtrate experiments. Development of postinfection toxicity in Orion tissue cultures and not in Majestic tissue cultures was found. To achieve an almost total exclusion of the infecting fungus, development of postinfectional toxicity would need to take place very rapidly. However, the development of toxicity in infected Orion tissue suspensions was very slow. This may have been due to an inability to detect the toxic principle until it had been produced in considerable quantities, because the ratio between the volume of the tissue culture liquid and the infected tissues was very high.

In some ways the reaction of the Orion tissue suspensions resembled the phytoalexin reactions described by Müller (1958) and Cruickshank (1963). Certain inconsistencies exist, however. For example, although the filtrate was toxic to zoospores from two strains of Phytophthora infestans, there was no toxicity to spores of Glomerella cingulata or Botrytis allii. The development of toxic substances in response to infection of Solanum tuberosum tissue cultures with $P$. infestans race 4 must be investigated further before any definite conclusions can be drawn. Tissue cultures differ in many ways from the intact potato plant (Steward \& Pollard, I956) and no direct comparison can be drawn between the two. However, if the results of the tissue culture experiments represent a model system of the processes normally involved in R-gene resistance, it is possible that the tissue culture method may provide results which will be of value in interpreting results already obtained, or in planning further experimentation to define more clearly the precise nature of the R-gene resistance of the potato.

My thanks are due to the Agricultural Research Council for financial support, and to Professor N. F. Robertson for advice and discussions.

\section{REFERENCES}

Blackwell, E. M. (1953). Haustoria of Phytophthora infestans and some other species. Trans. Br. mycol. Soc. 36, 138 .

Cruickshank, I. A. M. (1963). Phytoalexins. A. Rev. Phytopathology r, 35I.

FERrIs, V. R. (1955). Histological study of pathogen-suscept relationships between Phytophthora infestans and derivatives of Solanum demissum. Phytopathology 45, 546.

Gray, P. (1954). The Microtomist's Formulary and Guide, p. 287. London: Constable and Co. Ltd.

INGRAM, D. S. (1966). The interaction between Phytophthora infestans (Mont.) de Bary and tissue cultures of Solanum tuberosum. Ph.D. thesis, University of Hull.

Ingram, D. S. \& RoBertson, N. F. (1965). Interaction between Phytophthora infestans and tissue cultures of Solanum tuberosum. J. gen. Microbiol. 40, 43 I.

Johansen, A. J. (1940). Plant Microtechnique. New York: McGraw Hill Co. Inc.

LAPWOOD, D. H. \& MCKeE, R. K. (1961). Reaction of tubers of R-gene potato clones to inoculation with specialised races of Phytophthora infestans. Eur. Potato J. 4, 3. 
MCKeE, R. K. (1962). Identification of R-genes in Solanum stoloniferum. Euphytica II, 42.

MüLleR, K. O. (1950). Affinity and reactivity of Angiosperms to Phytophthora infestans. Nature, Lond. 166, 392.

MüLLER, K. O. (1958). Studies on phytoalexins. I. The formation and immunological significance of phytoalexin produced by Phaseolus vulgaris in response to infections with Sclerotinia fructicola and Phytophthora infestans. Aust. J. biol. Sci. Ir, 275.

MülLER, K. O. \& Börger, H. (1940). Experimentelle Untersuchugen über die Phytophthora-resistenz der Kartoffel. Arb. biol. BundAnst. Land- u. Forstw. 23, 189.

Steward, F. C. \& Pollard, J. K. (1956). Some further observations on glutamyl and related compounds in plants. In A Symposium on Inorganic Nitrogen Metabolism, p. 377. Baltimore: The Johns Hopkins Press.

Stoughton, R. H. (1930). Thionin and Orange $\mathrm{G}$ for the differential staining of bacteria and fungi in plant tissues. Ann. appl. Biol. 17, I62.

\section{EXPLANATION OF PLATE}

Fig. I. Eight replicate examples of Petri plates inoculated with tissue aggregates of Solanum tuberosum var. Orion and Phytophthora infestans (5 days). A, Tissues infected with $P$. infestans race $4 ; B$, tissues infected with $P$. infestans race 1 .

Fig. 2. Cell near the surface of a var. Orion tissue aggregate, packed with mycelium of Phytophthora infestans race 4. 

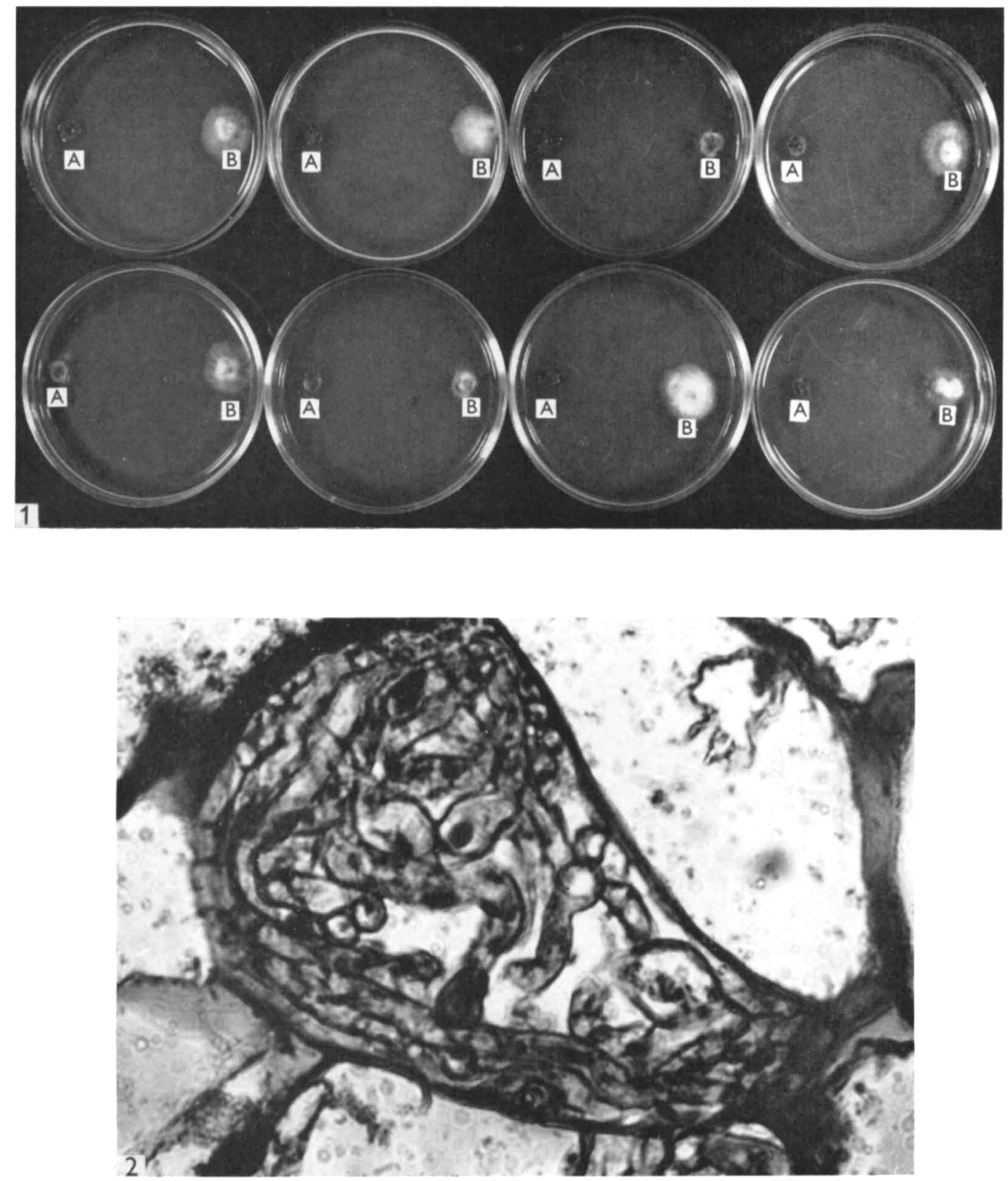